\title{
Hydroeconomic Models as Decision Support Tools for Conjunctive Management of Surface and Groundwater
}

\author{
Manuel Pulido-Velazquez, Guilherme F. Marques, Julien J. Harou, \\ and Jay R. Lund
}

\begin{abstract}
Conjunctive use (CU) of surface and groundwater storage and supplies is essential for integrated water management. It is also a key strategy for supporting groundwater-dependent ecosystems, and for adapting water systems to future climate and land use changes. CU has become increasingly sophisticated and integrated with other innovative and traditional water management techniques, such as water transfers, water reuse, demand management, and aquifer remediation. CU adds value for society (increasing average yield and reliability) but can also induce costs to some parties, such as damaging senior water rights of surface water users when pumping from the aquifer reduces streamflow. Groundwater overexploitation also can produce a host of undesirable economic and environmental impacts. Successful CU implementation typically requires changes in infrastructure and operations, but also changes in institutions and institutional arrangements to offset potential third party costs and protect ecosystems. This chapter analyses first the management and economic implications of $\mathrm{CU}$,
\end{abstract}

M. Pulido-Velazquez ( $\square$ )

Research Institute of Water and Environmental Engineering (IIAMA), Universitat Politècnica de València, Valencia, Spain

e-mail: mapuve@hma.upv.es

G.F. Marques

Instituto de Pesquisas Hidraulicas, Universidades Federal do Rio Grande do Sul, Porto Alegre, RS, Brazil

e-mail: guilherme.marques@ufrgs.br

J.J. Harou

School of Mechanical, Aerospace and Civil Engineering, The University of Manchester, Manchester, UK

e-mail: julien.harou@manchester.ac.uk

J.R. Lund

Center for Watershed Sciences, University of California, Davis, Davis, CA, USA

e-mail: jrlund@ucdavis.edu 
addressing advantages, costs and limitations, as well as the potential contribution of economic instruments to the conjunctive operation of groundwater and surface storage and resources. $\mathrm{CU}$ management models are then classified according to the $\mathrm{CU}$ problem, their formulation and solution techniques. Different applications of hydroeconomic models are reviewed in a wide range of $\mathrm{CU}$ problems. A few applications are discussed more in-depth, using cases from California and Spain. Then, we discuss the relevance of these models in decision-making, and the policy and institutional implications. Finally, we address limitations and challenges, and suggest future directions.

\subsection{Introduction: Conjunctive Use Overview}

Most regions in the world depend on a mixture of surface and groundwater to supply their water demands. This mix of supplies is especially important in semiarid and arid regions, where seasonal and annual variability in surface water is more pronounced, but humid regions also have seen increased importance of mixed surface and groundwater supplies as populations, environmental concerns, and water demands increase (Downing 1998). Historically, surface and groundwater sources have largely been developed, managed and used independently. However, as water resources in a region become increasingly exploited, population continues to grow, and water transfers become more controversial, the potential benefits of coordinated management of surface and groundwater supplies offer significant incentives for change.

Conjunctive use $(\mathrm{CU})$ of surface and groundwater resources has long been recognized as essential for integrated water management (Buras 1963; Burt 1967; Coe 1990). CU implies the coordinated management and use of surface and groundwater resources, taking advantage of their complementary properties. Although both surface and groundwater storages are used to redistribute water over time to match supply and demands, they differ in storage capacity, recharge and depletion rates, water quality, capital and operating costs, and physical, operational and institutional constraints. Jointly operating all manageable water resources in a region can increase the yield, efficiency, supply reliability and cost-effectiveness for a system. CU is also a key strategy for supporting groundwater-dependent ecosystems (Chap. 13; Kløve et al. 2011 and 2013), as well as for the adaptation of water resource systems to future climate and land use changes (Chaps. 4 and 5; Hanson et al. 2012).

Compared with surface storage, groundwater storage offers vast storage reserves, usually orders of magnitude larger than available surface storage in most watersheds. These reserves can help reduce or eliminate water shortages, acting as a "buffer stock" that provides a reliable, although informal, insurance system (Perez and Gómez 2013) Moreover, the great natural storage capacity of aquifers can be used to store excess surface water in wet periods, increasing ground water levels for use in subsequent dry periods. This could be achieved by artificial recharge techniques (Chaps. 16 and 17), or simply by alternating surface and groundwater use for irrigation, and taking advantage of the recharge coming from 
river and reservoir losses and the percolation of irrigated water (Sahuquillo and Lluria 2003). Aquifers provide a natural long-term water storage reservoir, without evaporation losses (except from very shallow aquifers). Efficient conjunctive operation increases supply by reducing losses from the freshwater system through reduced flow to the ocean or salt sinks and reduced evaporation from surface reservoirs (Coe 1990).

Groundwater bodies provide additional resources, but also means for water storage, distribution and treatment, which can be combined advantageously with surface water resources and facilities. $\mathrm{CU}$ can reduce drainage and salinity problems in irrigated and coastal areas, and water quality improvement is possible with more opportunities for blending water of different qualities and use of soil/aquifer media to treat water (SAT - soil aquifer treatment; see Fox et al. 2001). Initiatives in the US include the use of Aquifer Storage and Recovery (ASR) technologies in Florida, in the ambitious Comprehensive Everglades Restoration Plan (NRC 2012). The costly ASR component in the CU operations was avoided in Al Khamisia et al. (2013) by combining reclaimed water use directly with groundwater to meet irrigation demands. Conjunctive use may also facilitate the integration of reclaimed water to meet urban landscape irrigation demands (green strips and public gardens).

Despite all these advantages, the potential for $\mathrm{CU}$ of surface and groundwater has not been fully developed and implemented in many water systems. Traditionally, groundwater has been used only as a backup supply for times of shortage. Perhaps reflecting the bygone eras of their design, most large water supply systems continue to depend exclusively on surface water. Some physical, institutional and legal constraints make implementation of efficient conjunctive use management difficult. Physical and institutional factors promote, shape, and limit conjunctive management (Blomquist et al. 2004).

Conjunctive use operations involve diverse environmental, economic and social aspects, given that alterations in the natural cycle of surface water and groundwater are likely to cause costs and benefits not only to the directs users, but also the neighboring uses. The goals of the $\mathrm{CU}$ should be transparent and built with stakeholders' involvement and consensus, to avoid later conflicts. Communication is also critical for success. For example, conjunctive use operations using water banking will affect groundwater pumping costs to both users and neighbors due to the water table fluctuations during the refill and drawdown stages, causing both negative and positive externalities. If not properly taken into account and communicated, these may cause later litigation.

Further opportunities for conjunctive management can be exploited when an elaborate network of water infrastructure, water rights and institutions is present. Examples of these opportunities are found in California, where complex surface and groundwater problems have stimulated development of new approaches for conjunctive use. These approaches are focused mostly on integrating storage and conveyance infrastructure to allow more efficient and flexible water allocation and conservation, to broaden the range of beneficiaries and minimize water conflicts. The contemporary application of $\mathrm{CU}$ has become increasingly sophisticated and integrated with other innovative and traditional water management techniques, such 
as water transfers, water reuse, demand management, and aquifer remediation. The complexity of integrated water resources management in general, and conjunctive use in particular, requires methods and tools for predicting impacts and developing efficient and sustainable strategies.

In this chapter, after reviewing some economic and hydrologic tradeoffs of conjunctive management, we analyze the role of models and systems analysis techniques in the design of efficient planning and management strategies for conjunctive use schemes, using some examples from California (USA) and Spain.

\subsection{Economic and Hydrologic Tradeoffs of Conjunctive Use}

Some general economic advantages of conjunctive use include: greater water conservation, smaller surface water storage and distribution infrastructure, better flood control, ready integration with existing development, less danger from dam failure, and better timing of availability of water for distribution (Maknoon and Burges 1978). Conjunctive use schemes can provide other advantages, such as its adaptability to a progressive increase in water demand at a low cost, and the possibility of temporal overexploitation of aquifers to defer costly construction projects, mitigate the effects of droughts, or alleviate drainage problems (Sahuquillo 1985).

The main economic difference between ground and surface water projects is that, in general, initial investments are much lower for ground water, but operation and maintenance costs are higher. In surface water the initial investment is usually high and the operation and maintenance costs are small. An exception is that surface water treatment for urban uses usually requires higher energy and chemical costs (Sahuquillo 1989). Given the natural water distribution provided by groundwater, its integration in conjunctive use operations improves local supply availability, reducing reliance on external large-scale water transfers. To many regions, including California, this lowers operating costs and risks and increases sustainable operation. The latter also means higher investment locally (e.g. groundwater pumping and recharge infrastructure) contributing to local economic development rather than building large infrastructure elsewhere.

$\mathrm{CU}$ adds value for society, but also can induce costs to some parties as, for example, damaging senior water rights of surface water users when pumping from the aquifer reduces streamflow. Groundwater overexploitation can also produce a host of undesirable economic and environmental impacts. Adverse effects of overdraft can include: uneconomic pumping conditions, water quality degradation through induced intrusion of saline or poor quality groundwater, flow reduction in streams, wetlands and springs, land subsidence, interference with pre-existing water uses and water rights and a gradual depletion of groundwater storage (Sophocleous 2003; Zektser et al. 2005). CU is often the best solution to stop groundwater overdraft, transitioning to sustainable groundwater management with the least cost (Harou and Lund 2008). Successful CU implementation typically requires changes in 
infrastructure and operations, but also changes in institutions and institutional arrangements to offset potential third party costs and protect the ecosystems.

Although often underutilized, economic instruments are often decisive for water management to face increasing water scarcity problems. Water is often underpriced, leading to an imbalance between supply and demand and the unsustainable use of resources (NRC 1997). Water supply and demands vary over time and space, and water prices providing signals during times and locations where scarcity is higher can improve the efficiency of water use (Pulido-Velazquez et al. 2013). Some studies show that it is possible to increase welfare by using pricing to implement a conjunctive management strategy in which price signals encourage surface water use during wet years and groundwater use during dry years (e.g. Schuck and Green 2002; Riegels et al. 2013). In other cases, changes in surface water prices and costs affect the relative value of groundwater, reflecting on pumping patterns, operating costs and groundwater storage. Marques et al. (2006) investigate surface and groundwater economic uses in California, showing that lower groundwater pumping costs relative to surface water resulted in a system failure to internalize groundwater pumping externalities, as users switch to groundwater and aquifer overdraft is intensified. The overdraft raised future groundwater pumping costs, with potentially large economic impacts and risk to the feasibility of conjunctive use operations.

Flexible management of additional conjunctive use facilities and groundwater storage capacity under flexible water allocation can generate substantial economic benefits. CU adds operational flexibility to take better advantage of water market transfers, and transfers provide the allocation flexibility to take better advantage of conjunctive use (Pulido-Velazquez et al. 2004). The added flexibility afforded by conjunctive use reduces stress over the water system, especially surface water reservoirs which can be operated less conservatively when part of the storage is transferred to groundwater. This improves reliability and potential gains to all users, including environmental demands.

\subsection{Hydroeconomic Models Applied to Conjunctive Use}

The complexity of water resource systems requires methods to integrate technical, economic, environmental, legal, and social issues within a framework that develops efficient and sustainable water use strategies. Recent decades have seen widespread use of systems analysis to help on planning and management of water resources. This holistic approach requires identification, analysis and evaluation of the interactions among all components of water resource systems over space and time, considering physical and institutional constraints. Combining economic concepts and performance indicators with the modelling of the hydrologic system and infrastructure (hydroeconomic models, HEM) can provide results and insights more directly relevant for water management decisions and policies (Harou et al. 2009). Meanwhile, the common assumption of "stationary conditions" used 
in hydrologic and management modelling is nowadays under question in a context of accelerated climate change due to global warming and increasing changes in land uses (Milly et al. 2008), possessing new challenges for the modelers. In this context, hydroeconomic models are better prepared to integrate supply and demand management options to identify promising adaptive portfolios for future conditions.

\subsubsection{Model Components}

Most hydroeconomic models share basic components including hydrologic inflows, water management infrastructure, economic water demands, operating costs, and operating rules (Pulido-Velazquez et al. 2008; Harou et al. 2009). In CU models, we also need to characterize groundwater storage and heads (needed to assess pumping cost variation) and, of course, stream-aquifer interactions where significant for the management model and at the required level of accuracy (see Sect. 3.2). Figure 27.1 conceptually represents an HEM applied to conjunctive use management, illustrating the main components, modeled processes and results.

Water resource systems are often conceptualized as a flow network comprised of nodes, without (e.g. confluences or diversions) or with (reservoirs, aquifers) storage capacity, and links (natural or artificial conduits) with a limited capacity through which water moves in particular directions. A conjunctive use model should integrate surface and groundwater hydrology, as well as stream-aquifer interaction where this is relevant. While in non-economic system models, water demand is usually represented through fixed supply targets that have to be satisfied, HEMs require empirically-estimated marginal supply cost and benefit functions to establish the economic value of water supply to the different in-stream and off-stream

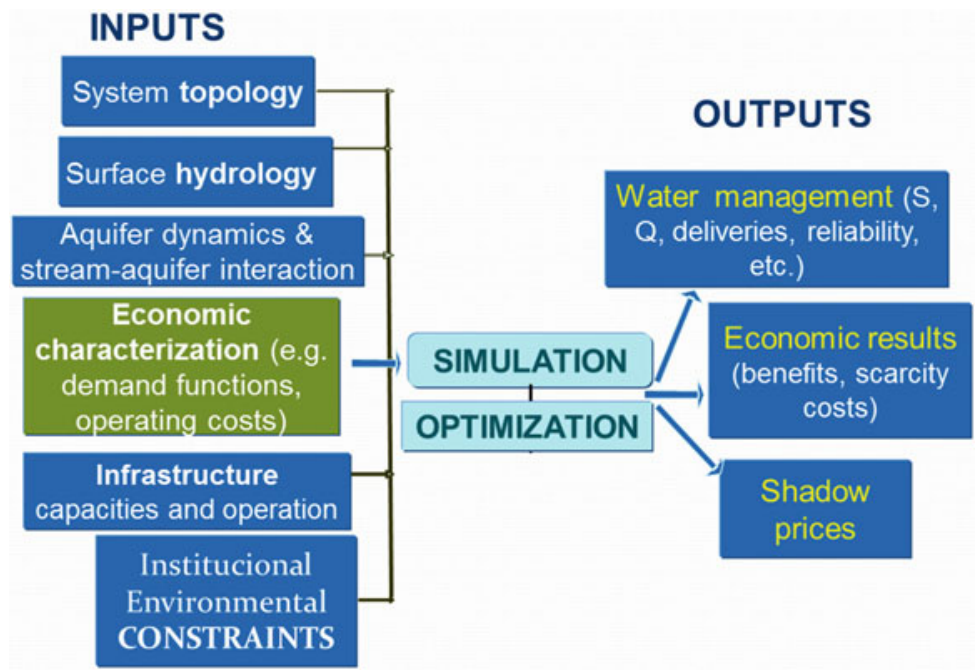

Fig. 27.1 Conceptual representation of HEM for conjunctive use management 
uses. The economic value of water can be characterized exogenously, using different valuation techniques (Young 2005) and external economic models for generating economic demand curves (representing the relation between the quantity of water delivered and its marginal value, ceteris paribus) (e.g. Jenkins et al. 2004; Pulido-Velazquez et al. 2004, 2006). The economic characterization also can be done endogenously, for example including crop production functions in the formulation of the HEM (e.g. Cai et al. 2003). Finally, the model can include different operational, environmental and institutional constraints. These constraints might be relaxed to investigate promising policy or management changes.

A variety of results are provided by HEMs, including flow and storage time series, benefits and costs, marginal economic value of water, and shadow prices for upper and lower bounds. These results can lead to useful conclusions on water allocation and operating decisions, as well as estimates of the economic values of changes in the management and/or the infrastructure capacity, opportunity costs, user's willingness to pay (see WTP coverage in Chap. 21) for water, and other economic and performance indicators (Pulido-Velazquez et al. 2008; Harou et al. 2009).

\subsubsection{Modelling Techniques}

\subsubsection{Hydraulic Management Versus Policy-Allocation Models}

$\mathrm{CU}$ management models with distributed aquifer simulation are often classified into hydraulic management models, and policy and allocation models (Gorelick 1983).

Hydraulic management models are principally concerned with managing flow, heads and mass transport in the aquifer. For example, optimal groundwater pumping constrained to subsidence control, the control of the evolution of a contaminant plume, or seawater intrusion control in a coastal aquifer. Although these models could be defined with an economic objective (such as maximizing the benefits of groundwater pumping or minimizing pumping cost), often they include other objectives such as maximizing total pumping, subject to the corresponding constraints on the aquifer response. Several examples of these types of optimization problems are provided in Ahlfeld and Mulligan (2000).

In contrast, policy evaluation and allocation models are mainly concerned with the efficient management and allocation of surface and groundwater resources (Bredehoeft 1995). Usually this approach is used in regional agriculturalmanagement problems (Bredehoeft and Young 1983; Lefkoff and Gorelick 1990; McCarl et al. 1999; Pulido-Velazquez et al. 2006) or in large multipurpose regional water supply systems, for example in California (Jenkins et al. 2004; PulidoVelazquez et al. 2004). The objective function is often defined as maximizing the total economic value of water allocation over time, so that the model will explore the optimal distribution of resources in space and time across the different competing sectors. The economic value of water use is often defined for each use using economic demand curves. 
An alternative approach is allocation models in which conjunctive use management is defined based on existing water allocation priorities, without including any explicit economic representation (eg. Fredericks et al. 1998; Pulido-Velazquez et al. 2002).

\subsubsection{Simulation Versus Optimization Models}

Simulation or descriptive models that assess system performance for predefined alternative strategies ("what if" scenarios), permit a more detailed and realistic representation of complex systems, since they are not limited by many of the simplifications needed by the optimization models. In this sense, simulation models are essential for analyzing complex processes of surface and subsurface flow and transport. In groundwater hydrology, the most common models for solving flow and transport equations are based on finite difference or finite element techniques (Anderson and Woesneer 1992). HEM applications usually compare a baseline scenario considering current facilities and operations constrained to current allocation policies with alternative policy scenarios with or without new infrastructure to assess the tradeoffs of a change in system management or design in terms of costs and benefits (Pulido-Velazquez et al. 2008).

Prescriptive optimization models are particularly useful to systematically search for promising planning/management solutions ("what's best" scenarios). A great variety of conjunctive use optimization models are available in the literature, both for hydraulic management and for policy-allocation (as defined in the previous section). Such models typically use linear, non-linear or dynamic techniques with a dynamic balance of relevant quantities (e.g. water flow, contaminant mass), appropriate constraints, and a single (usually economic) or a multiple (e.g. economic, social, target demand) objective (Lall 1995). Network flow programming has been applied for large systems assuming linear or piece-wise linearized responses (Jenkins et al. 2004). Heuristic or nonexact methods like simulated annealing and genetic algorithms have been used for tackling the difficulties of nonlinear nonconvex problems (Rao et al. 2004). Fuzzy approaches allow to deal with uncertainty or account for expert management (Safavi and Alijanian 2011). "Black-box" neural networks approaches have been also employed to simulate groundwater response functions (Karamoutz et al. 2007). There is no general algorithm for solving these problems, but rather the choice of the solver will depend on the characteristics of the system, the scope of the model, the data availability, and the specified objectives and constraints.

\subsubsection{Representing Groundwater and Stream-Aquifer Interaction in Conjunctive Use Models}

Two types of models have been used to quantify stream-aquifer interaction: lumped and distributed-parameter models. Lumped-parameter models use a few parameters to represent the average behavior of the system (e.g., the bathtub model). Most theoretical and empirical economic studies of optimal groundwater management have presented groundwater dynamics using a single-cell bathtub aquifer model, to derive optimal temporal groundwater exploitation (e.g., Burt 1967) or compare 
optimal management versus competitive myopic solutions (e.g., Gisser and Sanchez 1980; Koundouri 2004). However, other studies have shown that optimal pumping behavior predicted by single-cell bathtub models, which assume that an aquifer responds uniformly and instantly to groundwater pumping, can differ significantly from results of more realistic spatially explicit models with finite hydraulic conductivity (Brozović et al. 2006). Bredehoeft and Young (1970) and Young and Bredehoeft (1972) also showed the importance of an accurate distributed modeling of the aquifer system for conjunctive management purposes, the importance of pumping allocation and the need to manage surface and groundwater as a unit in order to achieve the maximum net benefit. In large-scale River Basin Hydroeconomic (RBHE) models, aquifers are often represented as simple reservoirs with a mass balance equation, often due to the constraints imposed by the applied optimization algorithm (as in network flow optimization models) or the lack of data or more accurate representation.

The linear reservoir model is the simplest model for stream-aquifer connections, and it has been used in simulation and optimization models to indicate promising conjunctive use alternatives at an initial planning stage (e.g., Buras 1963). To analyze a groundwater system with greater accuracy requires a distributed model that explicitly considers the spatial distribution of the aquifer and its hydrodynamic properties, the boundary conditions and the location of external stresses. Analytical solutions have been often useful for a preliminary assessment of stream-aquifer, but most available solutions are developed for ideal homogenous and isotropic aquifers of infinite or semi-infinite extent, idealistic assumptions that can have a significant effect on the accuracy of the results of streamflow depletion (Sophocleous et al. 1995; Pulido-Velazquez et al. 2005). The integration of distributed-parameter models within integrated RBHE optimization models has significant computational implications, and an efficient tool for aquifer simulation is desirable to derive optimal management alternatives or evaluate many alternatives for integrated management over long periods of time. Two major techniques for incorporating distributed groundwater flow simulation within a conjunctive use management optimization model are: the embedding and the response matrix methods (Gorelick 1983; Peralta et al. 1995). A third approach for groundwater flow modeling in basinwide management models is the Eigenvalue Method (Sahuquillo 1983; Andreu and Sahuquillo 1987), in which piezometric heads, flux vectors, and surface and groundwater interactions are obtained by explicit state equations. Unlike the 'embedding method', only the equations that define the control or state variables are loaded into the sets of constraints of the optimization model to simulate groundwater flows, offering computational advantages for the integration of linear distributed-parameter groundwater simulation models within complex conjunctive use models over a long time horizon (Andreu and Sahuquillo 1987; Pulido-Velazquez et al. 2006, 2007a). The Embedded Multireservoir Method also allows quantifying stream-aquifer interaction by simple and operational explicit state equations (Pulido-Velazquez et al. 2005).

\subsubsection{Ad-hoc Models Versus Decision Support Systems (DSS) Shells}

DSSs are interactive computer-based tools to assist in decision-making when addressing complex management problems, integrating simulation and 
optimization models (Chap. 25). DSSs often involve capabilities of computer assisted graphical design, geographically referenced data bases, and interactive and user-friendly graphical interfaces and tools for input management, results display and analysis. Some examples of DSS with conjunctive use capabilities, such as CALVIN (Jenkins et al. 2004), MODSIM (Fredericks et al. 1998), WEAP (Yates et al. 2005) or AQUATOOL (Andreu et al. 1996), although with significant differences in how water resource systems and conjunctive use are modeled and optimized.

\subsection{Selected Applications}

\subsubsection{CU Management in Southern California}

Southern California's water system imports up to $70 \%$ of its water use, with groundwater being a critical component of the region's water supply. While California's population is expected to increase significantly over the next few decades, on the supply side, traditional imports from the Colorado River and the Owens and Mono Basins are being curtailed, creating a significant water crisis (Chung et al. 2002). The economic-engineering network flow optimization model CALVIN has been used to analyze and compare the economic and reliability benefits from different conjunctive use alternatives (Pulido-Velazquez et al. 2004; Harou and Lund 2008). Results from CALVIN suggest that flexible management of additional conjunctive use facilities and groundwater storage capacity under flexible water allocation can generate substantial economic benefits to the region. Conjunctive use adds operational flexibility needed to take full advantage of water transfers, and transfers provide the allocation flexibility needed to take better advantage of conjunctive use. The value of projected conjunctive use facilities and groundwater storage along the Colorado River Aqueduct, Coachella Valley, and north of the Tehachapi mountains under economically optimized operation of the system is examined. The results reveal reduction of the demand for increased imports into Southern California, suggest changes in the system operations, and indicate significant economic benefits from expanding some conveyance and storage facilities.

\subsubsection{CU Operations and Irrigated Agriculture Decisions in California}

Simulation and optimization models often have been used to support effective conjunctive programs and operations, including approaches with physical stream/ aquifer interaction (Gorelick 1983; Peralta et al. 1995; Fredericks et al. 1998; Belaineh et al. 1999) and operating decisions to minimize surface reservoir spills (Schoups et al. 2006a, b). While these approaches help the understanding of surface 
and groundwater interaction, and how to manage it, its application to local management still lacks representation of detailed users' decisions behind water demands, including water and irrigation technology use under uncertain (stochastic) surface water supplies.

In California, federal, tribal, state and local agencies are responsible for managing surface and groundwater, including water rights regulation, groundwater quality and groundwater management plans. According to the California Department of Water Resources (DWR 2009) water users have few restrictions on groundwater use (except in adjudicated basins) as long as the water is applied to beneficial use. This may cause environmental and economic problems if there is not a proper integrated management of surface and groundwater supplies.

In this context, the hydroeconomic model presented in Marques et al. (2010) addresses farm decisions of water use and crop production. Surface and groundwater are conjunctively managed through artificial recharge to store surface water in the aquifer, and groundwater pumping to retrieve it. Artificial recharge occurs through spreading areas for infiltration, which requires some land dedicated to it. The hydroeconomic model includes surface and groundwater supply and storage, each with its costs, availability, uncertainty and use constraints, integrated with the economic product function of the user, which has water as one of the inputs. This allows the model to capture user decisions on which supply source to use, how efficiently to use it (irrigation technology), when and how much to use.

The approach is based on a two-stage stochastic programming model combining a quadratic crop profit function with permanent and temporary irrigation water use decisions to identify the potential economic gains of conjunctive use operations, and how such operations can be organized. Permanent crop decisions are modeled in the first stage, and annual (temporary) crops are modeled in the second stage, represented by a group of possible hydrologic scenarios (dry and wet years), each with a different water availability and probability of occurrence. In any hydrologic scenario, water can be withdrawn from surface supplies and pumped from the aquifer to irrigate crops, or artificially recharged for posterior use. Conjunctive use operations are represented by additional decision variables for artificial recharge area, volumes recharged and pumped. An intertemporal mass balance equation ensures aquifers recharge matches pumping in the long run to avoid aquifer overdraft. The model maximizes the net expected economic benefit of irrigated crop production in both stages, with conjunctive use operations allowing water to be transferred between different hydrologic scenarios through artificial groundwater pumping and recharge (Fig. 27.2) which is integrated with surface water use and availability.

The model application in Marques et al. (2010) indicated that groundwater availability, price, and conjunctive use operations affect crop and irrigation technology decisions. Groundwater provides a stabilizing effect, increasing permanent (more valuable) crop acreage and expanding annual crops in dry years. Crops with high consumptive demand were not supplied with costly water through low efficiency irrigation technology, and as groundwater supply was curtailed in wet years, surface water was allocated to permanent (more valuable) crops, reducing the 


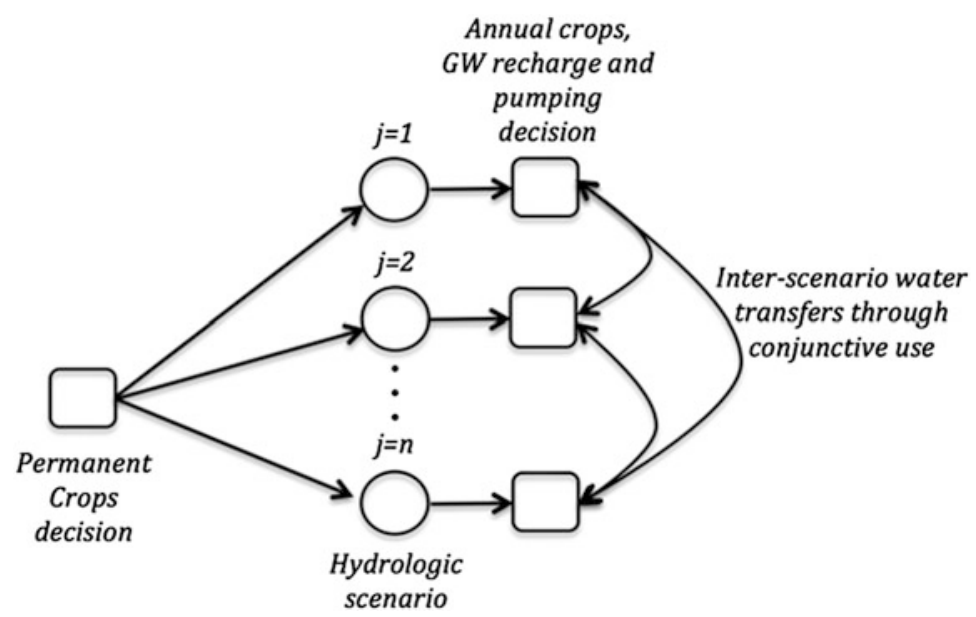

Fig. 27.2 Diagram of hydroeconomic model decision structure

acreages of annual crops. Artificial recharge was concentrated in very wet years, to take most advantage of the investment in infrastructure. With conjunctive use operations, the gains in income reliability were greater than the gains in the expected net benefit, with a trade-off between both. This information can be useful to evaluate the user's willingness-to-pay for insurance based on risk aversion. While users are likely to increase investment in groundwater pumping capacity, sacrificing some of the total net return gains to build the CU infrastructure, the model allowed the identification of a maximum groundwater pumping capacity investment beyond which no further benefits were expected in reliability or net benefit.

\subsubsection{Economically Optimal CU in the Adra-Campo de Dalias System (Spain)}

In the coastal plain of Campo de Dalias $\left(330 \mathrm{~km}^{2}\right)$ in Almeria province, southeastern Spain, the climate conditions and the application of high-tech agricultural techniques have led to high value crop production, mostly vegetables produced under greenhouses, with a spectacular increase in cultivated land and population, becoming the main factor of economic growth in the province. In this water scarce arid region, the water for the irrigation of the more than 20,000 ha. of cultivated land is obtained from groundwater pumping from the Campo de Dalias aquifer system. The intense use of groundwater for years has led to a significant decline of the water table, causing problems of water availability and quality (e.g. seawater intrusion problems). To reduce overexploitation of the Campo aquifers, water is being imported, beginning in 1987, from the Beninar Reservoir, located in the contiguous Adra River basin.

Pulido-Velazquez et al. (2002) examined different conjunctive use management alternatives for the system in a detailed simulation study. An integrated hydrologic- 
economic modeling framework for optimizing conjunctive use of surface and groundwater has also been developed for the Adra-Campo de Dalias system (Pulido-Velazquez et al. 2006, 2008). Integrated river basin modeling with distributed groundwater simulation and dynamic stream-aquifer interaction allows a more realistic representation of conjunctive use and the associated economic results. Transient distributed-groundwater flow is simulated by embedding the explicit equations derived from the eigenvalue method (Sahuquillo 1983) as constraints within the nonlinear economic-engineering optimization model. This method provides an efficient approach for aquifer modeling in conjunctive use models, using explicit state equations to characterize the selected state variables. The use of an economic objective function, maximizing the net economic value of water use, provides solutions that optimize economic efficiency in water resources management, while the model constraints guarantee the feasibility and sustainability of suggested operations.

The model results include time series of monthly flow and storage, marginal economic value of water at each location and time step, and shadow prices for upper or lower bounds in reservoirs, stream reaches, canals, and pipelines. These results lead to conclusions on water allocation and operating decisions, as well as estimates of the economic value of changes in the management and/or the capacity of the infrastructure, users' willingness-to-pay for water, and other economic and performance indicators. A systematic approach is provided to estimate time-varying resource and environmental constraint opportunity costs to users at different locations within the system, providing useful indicators for the economic analysis required by the EU Water Directive Framework (Pulido-Velazquez et al. 2006, 2008; Heinz et al. 2007).

\subsection{Challenges, Benefits and Future Directions}

Many choices face the builder of a hydroeconomic conjunctive use model, including the scale and model type for each of the three subsystems (surface water, groundwater and economic demands). Most modeling efforts showcase unique combinations of these because of unique characteristics of the modeled system and the modeler's skills and perspectives. In practice existing models, especially if calibrated and accepted by stakeholders, often influence decisions about how to build an integrated model. A major choice is whether the groundwater model will be lumped (a frequent choice for policy models) or spatially distributed (often appropriate for hydraulic management models). Other decisions, like which water use benefits to include and how to represent their economic values, are shared with all hydroeconomic models and are not particular to conjunctive use hydroeconomic models. This is the case for choosing an appropriate temporal discretization (timestep) and when optimization is used, whether the optimization model should be solved all at once (water users in the model have perfect knowledge of future hydrological flows) or time-step by time-step. 
There are several technical challenges to hydroeconomic modeling of conjunctive use of surface and groundwater. For example, in conjunctive use systems nonlinearities may arise due to the physical representation of the system (e.g. nonlinearities due to stream disconnection in stream-aquifer interaction or unconfined aquifers) or the cost structure for surface and groundwater use (e.g. nonlinearity of pumping costs, function of the product of pumping heads and pumping rates at the production well). In simulations models, this can be easily addressed. But for hydroeconomic models using optimization approaches, the potential non-linearities of stream-aquifer interactions, unconfined aquifers or pumping cost functions, introduces difficulties in solving the model and in the verification that the solution is globally optimal. Several researchers have overcome these difficulties in particular modeling efforts (Reichard 1987; Pulido-Velazquez et al. 2006, 2007b, etc.). Still it is a barrier in practice as these are specialty methods known to few practitioners. Hydroeconomic modeling conjunctive studies that use optimization algorithms to solve all governing equations including large sets of discretized spatially explicit groundwater equations may fall prey to numerical difficulties (e.g. Tung and Koltermann 1985; Harou and Lund 2008). Other studies have not reported difficulties in this task but it remains a potential challenge or barrier, particularly for large groundwater models.

Despite early and on-going successes, advanced modeling of conjunctive use in water supply planning and management industry practice is the exception rather than the rule. Often excellent surface water system modeling and groundwater modeling systems exist, but their combined use by industry is still rare globally, with more use in some areas (e.g. California, Spain, Australia, etc.). In water supply planning by utilities, where conjunctive use modeling would be particularly valuable, groundwater is often still represented as an aggregated available supply (e.g. yield). The groundwater field has repeatedly warned against 'safe yield' concepts applied to groundwater (Alley and Leake 2004), yet because adopting this approach means integrating groundwater sources into basic supply-demand models is feasible (e.g. Padula et al. 2013), it persists. Also, many decision support systems built for utility scale water supply planning start with the surface water network and its storage reservoirs; this encourages inclusion of groundwater as another storage node. WEAP (Yates et al. 2005) and AQUATOOL (Andreu et al. 1996) are notable exceptions as they allow linking discretized groundwater models to a surface water resource management model.

The papers and modeling efforts reviewed here show the potential benefits to water management studies of considering hydroeconomic aspects of conjunctive use management systems. These include, amongst others, suggesting how groundwater and surface sources can most productively be used together, how use of each resource economically affects those exploiting the other, how the two resources can efficiently interact within water markets, and how new schemes can have unexpected but significant impacts on other water supplies, either downstream or in the future. These are major benefits and, given the large capital cost of water supply investments, they are in many situations worth the investment. Below we review what future directions this field could take to achieve further scientific and practical impact. 
Future potential scientific directions of inquiry are many, starting with the continued improvement of current models and methods for integrated modeling of surface and groundwater and their link to managed systems. Linked groundwater models and surface water simulation can now be linked to single or multi-objective global search algorithms (Reed et al. 2013; Matrosov et al. 2015); this new way to seek efficient solutions opens up many possibilities, including simultaneously considering non-economic objectives. Recent efforts (Yang et al. 2009; Giuliani and Castelletti 2013; Erfani et al. 2013) to move beyond deterministic optimization to represent more realistic behavioral modeling of water users are relevant here. Many optimization modeling efforts reviewed in the paper apply to situations where water markets are relevant; where this is not the case, different computational technologies may be appropriate. Including specific policy investigations (e.g. pricing; Riegels et al. 2013) in addition to water allocation assessment will increase as the tools under discussion are used to assess particular policy investigations.

Several factors could influence growth of hydroeconomic conjunctive use modeling from pockets of excellence (e.g. Western USA, Spain and other localized contexts) to increased global use. The demand from stakeholders and water planners and the availability of easy-to-use decision support systems that model both surface and groundwater systems will likely determine how influential conjunctive use models will be in the future. If their use continues to grow, it is likely that such models with an added hydroeconomic focus will move from academia, their current most frequent institutional home, further into practice.

Open Access This chapter is distributed under the terms of the Creative Commons AttributionNoncommercial 2.5 License (http://creativecommons.org/licenses/by-nc/2.5/) which permits any noncommercial use, distribution, and reproduction in any medium, provided the original author(s) and source are credited.

The images or other third party material in this chapter are included in the work's Creative Commons license, unless indicated otherwise in the credit line; if such material is not included in the work's Creative Commons license and the respective action is not permitted by statutory regulation, users will need to obtain permission from the license holder to duplicate, adapt or reproduce the material.

\section{References}

Ahlfeld DP, Mulligan A (2000) Optimal management of flow in groundwater systems. Academic, New York

Al Khamisia SA, Prathapar SA, Ahmed M (2013) Conjunctive use of reclaimed water and groundwater in crop rotations. Agric Water Manage 116:228-234

Alley WM, Leake SA (2004) The journey from safe yield to sustainability. Ground Water 42 (1):12-16

Anderson MP, Woessner WW (1992) Applied groundwater modeling. Simulation of flow and advective transport. Academic, San Diego

Andreu J, Sahuquillo A (1987) Efficient aquifer simulation in complex system. J Water Resour Plan Manage 113(1):110-129 
Andreu J, Capilla J, Sanchis E (1996) AQUATOOL, a generalized decision support system for water-resources planning and management. J Hydrol 177:269-291

Belaineh G, Peralta RC, Hughes TC (1999) Simulation/optimization modeling for water resources management. J Water Resour Plan Manage 125(3):154-161

Blomquist WA, Schlager E, Heikkila T (2004) Common waters, diverging streams: linking institutions and water management in Arizona, California, and Colorado. RFF Press, Baltimore

Bredehoeft JD (1995) If it works, don't fix it: benefits from regional groundwater management. In: El-Kadi AI (ed) Groundwater models for resources analysis and management. Lewis Publishers, Boca Raton

Bredehoeft JD, Young RA (1970) The temporal allocation of ground water - a simulation approach. Water Resour Res 6(1):3-21

Bredehoeft JD, Young RA (1983) Conjunctive use of groundwater and surface water for irrigated agriculture: risk aversion. Water Resour Res 19(5):1111-1121

Brozović N, Sunding D, Zilberman D (2006) Optimal management of groundwater over space and time. In: Frontiers in water resource economics. Springer, New York, pp 109-135

Buras N (1963) Conjunctive operation of dams and aquifers. Proc ASCE 89(HY. 6):11-131

Burt OR (1967) Temporal allocation of groundwater. Water Resour Res 3(1):45-56

Cai X, McKinney DC, Lasdon LS (2003) Integrated hydrologic-agronomic-economic model for river basin management. J Water Resour Plan Manage 129(1):4-17

California Department of Water Resources, DWR (2009) California water plan update - resource management strategies - conjunctive management and groundwater, vol 2, chapter 8

Chung F, Kelly KK, Guivetchi K (2002) Averting a California crisis. J Water Resour Plan Manage 128(4):237-239

Coe JJ (1990) Conjunctive use - advantages, constraints, and examples. J Irrig Drain Eng 116 (3):427-443

Downing R (ed) (1998) Groundwater, our hidden asset. British Geological Survey/Earthwise Popular Science Books, Nottinghan, $59 \mathrm{p}$

Erfani T, Huskova I, Harou JJ (2013) Tracking trade transactions in water resource systems: a node-arc optimization formulation. Water Resour Res 49:3038-3043

Fox P, Narayanaswamy K, Genz A, Drewes JE (2001) Water quality transformations during soil aquifer treatment at the Mesa Northwest Water Reclamation Plant, USA. Water Sci Technol 43:343-350

Fredericks JW, Labadie JW, Altenhofen JM (1998) Decision support system for conjuctive stream-aquifer management. J Water Resour Plan Manage 124(2):69-78

Gisser M, Sanchez DA (1980) Competition versus optimal control in groundwater pumping. Water Resour Res 16(4):638-642

Giuliani M, Castelletti A (2013) Assessing the value of cooperation and information exchange in large water resources systems by agent-based optimization. Water Resour Res 49:3912-3926

Gorelick SM (1983) A review of distributed parameter groundwater management modeling methods. Water Resour Res 19(2):305-319

Hanson RT, Flint LE, Flint AL, Dettinger MD, Faunt CC, Cayan D, Schmid W (2012) A method for physically based model analysis of conjunctive use in response to potential climate changes. Water Resour Res 48:W00L08. doi:10.1029/2011WR010774

Harou JJ, Lund JR (2008) Ending groundwater overdraft in hydrologic-economic systems. Hydrogeol J 16(6):1039-1055

Harou JJ, Pulido-Velazquez M, Rosenberg DE, Medellin-Azuara J, Lund JR, Howitt RE (2009) Hydro-economic models: concepts, design, applications, and future prospects. J Hydrol 375 (3-4):627-643. doi:10.1016/j.jhydrol.2009.06.037

Heinz I, Pulido-Velazquez M, Lund JR, Andreu J (2007) Hydro-economic modeling in river basin management: implications and applications for the European water framework directive. Water Resour Manage 21(7):1103-1125

Jenkins MW, Lund JR, Howitt RE, Draper AJ, Msangi SM, Tanaka SK, Ritzema RS, Marques GF (2004) Optimization of California's water system: results \& insights. J Water Resour Plan Manage 130(4):271-280 
Karamouz M, Tabari M, Kerachian R (2007) Application of genetic algorithms and artificial neural networks in conjunctive use of surface and groundwater resources. Water Int 32(1):163-176

Kløve B, Allan A, Bertrand G et al (2011) Groundwater dependent ecosystems. Part II. Ecosystem services and management in Europe under risk of climate change and land use intensification. Environ Sci Policy 14(7):782-793

Kløve B, Ala-Aho P, Bertrand G, Gurdak JJ, Kupfersberger H, Kværner J, Muotka T, Mykrä H, Preda E, Rossi P, Uvo CB, Velasco E, Pulido-Velázquez M (2013) Climate change impacts on groundwater and dependent ecosystems. J Hydrol 518:250-266

Koundouri P (2004) Potential for groundwater management: Gisser-Sanchez effect reconsidered. Water Resour Res 40. doi:10.1029/2003WR002164

Lall U (1995) Yield model for screening surface and ground water development. J Water Resour Plan Manage 121(1):9-22

Lefkoff J, Gorelick SM (1990) Benefits of an irrigation rental market in a saline stream-aquifer system. Water Resour Res 26(7):1371-1381

Maknoon R, Burges SJ (1978) Conjunctive use of surface and groundwater. Am Water Works Assoc J 78(8):419-424

Marques GF, Lund JR, Leu MR, Jenkins M, Howitt R, Harter T, Hatchett S, Ruud N, Burke S (2006) Economically driven simulation of regional water systems: Friant-Kern, California. J Water Res Plan Manage 132(6):468-479

Marques G, Lund JR, Howitt R (2010) Modeling conjunctive use operations and farm decisions with two-stage stochastic quadratic programming. J Water Resour Plan Manage 136(3):386-394

Matrosov ES, Huskova I, Kasprzyk JR, Harou JJ, Lambert C, Reed PM (2015) Many-objective optimization and visual analytics reveal key trade-offs for London's water supply. J Hydrol. doi:10.1016/j.jhydrol.2015.11.003

McCarl BA, Dillon CR, Keplinger KO, Williams RL (1999) Limiting pumping from the Edwards Aquifer: an economic investigation of proposals, water markets, and spring flow guarantees. Water Resour Res 35(4):1257-1268

Milly PCD, Betancourt J, Falkenmark M et al (2008) Stationarity is dead: whither water management? Science 319:573-574

NRC (1997) Valuing ground water. Economics concepts and approaches. National Research Council/National Academic Press, Washington, DC

NRC (2012) Progress toward restoring the Everglades: the fourth biennial review, 2012. National Research Council/National Academies Press, Washington, DC

Padula S, Harou JJ, Papageorgiou LG, Ji L, Mohammad A, Hepworth N (2013) Least economic cost regional water supply planning - optimising infrastructure investments and demand management for South East England's 17.6 million people. Water Resour Manag 27 (15):5017-5044

Peralta RC, Cantiller RA, Terry JE (1995) Optimal large-scale conjunctive water-use planning: case study. J Water Resour Plan Manage 121(6):471-478

Perez CD, Gómez CM (2013) Designing optimum insurance schemes to reduce water overexploitation during drought events: a case study of La Campiña, Guadalquivir River Basin, Spain. J Environ Econ Policy 2(1):1-15. doi:10.1080/21606544.2012.745232

Pulido-Velazquez M, Andreu J, Sahuquillo A, Pinilla V, Sánchez A, Capilla J, Paredes J (2002) Optimization of water resources management under aquifer overexploitation conditions. In: Brebia CA, Blain WR (eds) Hydraulic information management, 488 pp. WIT Press, Southampton, UK

Pulido-Velazquez M, Jenkins MW, Lund JR (2004) Economic values for conjunctive use and water banking in southern California. Water Resour Res 40(3):W03401

Pulido-Velazquez M, Sahuquillo A, Ochoa JC, Pulido-Velazquez D (2005) Modeling of streamaquifer interaction: the embedded multireservoir model. J Hydrol 313(3-4):166-181

Pulido-Velazquez M, Sahuquillo A, Andreu J (2006) Economic optimization of conjunctive use of surface and groundwater at the basin scale. J Water Resour Plan Manage 132(6):454-467

Pulido-Velazquez D, Sahuquillo A, Andreu J, Pulido-Velazquez M (2007a) An efficient conceptual model to simulate surface water body-aquifer interaction in conjunctive use management models. Water Resour Res 43(7):W07407 
Pulido-Velazquez D, Sahuquillo A, Andreu J, Pulido-Velazquez M (2007b) A general methodology to simulate groundwater flow of unconfined aquifers with a reduced computational cost. $\mathrm{J}$ Hydrol 338(1-2):42-56

Pulido-Velazquez M, Andreu J, Sahuquillo A, Pulido-Velazquez D (2008) Hydro-economic river basin modelling: the application of a holistic surface-groundwater model to assess opportunity costs of water use in Spain. Ecol Econ 66(1):51-65

Pulido-Velazquez M, Alvarez-Mendiola E, Andreu J (2013) Design of efficient water pricing policies integrating basinwide resource opportunity costs. J Water Resour Plan Manage 139 (5):583-592

Rao SVN, Bhallamudi SM, Thandaveswara BS, Mishra GC (2004) Conjunctive use of surface and groundwater for coastal and deltaic systems. J Water Resour Plan Manage 130(3):255-267

Reed PM, Hadka D, Herman J, Kasprzyk J, Kollat J (2013) Evolutionary multiobjective optimization in water resources: the past, present, and future. Adv Water Resour 51:438-456

Reichard EG (1987) Hydrologic influences on the potential benefits of basinwide groundwater management. Water Resour Res 23(1):77-91

Riegels N, Pulido-Velazquez M, Doulgeris C, Valerie S, Jensen R, Moller F, Bauer-Gottwein P (2013) A systems analysis approach to the design of efficient water pricing policies under the EU water framework directive. J Water Res Plan Manage 139(5):574-582

Safavi H, Alijanian M (2011) Optimal crop planning and conjunctive use of surface water and groundwater resources using fuzzy dynamic programming. J Irrig Drain Eng 137(6):383-397

Sahuquillo A (1983) An eigenvalue numerical technique for solving unsteady groundwater models continuously in time. Water Resour Res 19(1):87-93

Sahuquillo A (1985) Groundwater in water resources planning: conjunctive use. Water Int 10 (2):57-63

Sahuquillo A (1989) The economic aspects of the conjunctive use of ground and surface water. In: Groundwater economics: selected papers from an UN symposium in Barcelona, Spain. Develop. in Water Science, vol. 39. Elsevier, Amsterdam

Sahuquillo A, Lluria M (2003) Conjunctive use as potential solution for stressed aquifers: social constraints. In: Llamas MR, Custodio E (eds) Intense use of groundwater. Challenges and opportunities. Balkema Publishers, Lisse

Schoups G, Addams CL, Minjares JL, Gorelick SM (2006a) Reliable conjunctive use rules for sustainable irrigated agriculture and reservoir spill control. Water Resour Res 42: W12406. doi:10.1029/206WR005007

Schoups G, Addams CL, Minjares JL, Gorelick SM (2006b) Sustainable conjunctive water management in irrigated agriculture: model formulation and application to the Yaqui Valley, Mexico. Water Resour Res 42(10): W10417. doi:10.1029/2006WR004922

Schuck EC, Green GP (2002) Supply-based water pricing in a conjunctive use system: implications for resource and energy use. Resour Energy Econ 24(3):175-192

Sophocleous M (2003) Environmental implications of intensive groundwater use with special regard to streams and wetlands. In: Llamas R, Custodio E (eds) Intensive use of groundwater. CRC Press, The Netherlands

Sophocleous M, Koussis A, Martin JL, Perkins SP (1995) Evaluation of simplified stream-aquifer depletion models for water rights administration. Ground Water 4(3):579-588

Tung YK, Koltermann CE (1985) Some computational experiences using embedding technique for ground-water management. Ground Water 23(4):455-464

Yang Y-CE, Cai X, Stipanović DM (2009) A decentralized optimization algorithm for multi-agent system based watershed management. Water Resour Res 45:W08430

Yates D, Sieber J, Purkey D, Huber-Lee A (2005) WEAP21-a demand-, priority-, and preferencedriven water planning model part 1: model characteristics. Water Int 30(4):487-500

Young RA (2005) Determining the economic value of water: concepts and methods. Resources for the Future, Washington, DC

Young RA, Bredehoeft JD (1972) Digital computer simulation for solving management problems of conjunctive groundwater and surface water systems. Water Resour Res 8(3):533-556

Zektser S, Loaiciga HA, Wolf JT (2005) Environmental impacts of groundwater overdraft: selected case studies in the southwestern United States. Environ Geol 47:396-404 